\title{
Molecular Epidemiology and Clinical Characteristics of Metallo- beta-lactamase Producing Pseudomonas aeruginosa Isolates
}

\author{
Metallo-Beta Laktamaz Üreten Pseudomonas aeruginosa Suşlarının Moleküler \\ Epidemiyolojisi ve Klinik Özellikleri
}

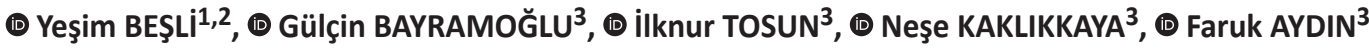 \\ ${ }^{1}$ Aclbadem University Faculty of Medicine, Department of Medical Microbiology, istanbul, Turkey \\ ${ }^{2}$ Acıbadem Labmed Clinical Laboratories, Istanbul, Turkey \\ ${ }^{3}$ Karadeniz Technical University Faculty of Medicine, Department of Medical Microbiology, Trabzon, Turkey
}

\section{Abstract}

Introduction: In this study, we aimed to determine the epidemiological properties of metallo-beta-lactamase-producing Pseudomonas aeruginosa (MBL-PA) isolates and to investigate the relationship between the presence of MBL-PA and patient morbidity and mortality.

Materials and Methods: The study included carbapenem-resistant $P$. aeruginosa isolates recovered from various clinical specimens of 334 patients in Karadeniz Technical University Faculty of Medicine Hospital, a 900-bed university hospital in Trabzon, Turkey. MBL-related carbapenem-resistant PA strains were phenotypically investigated using the Modified Hodge test and the imipenem/imipenem-ethylene diamine tetra acetic acid combined disc tests. Multiplex polymerase chain reaction was used to investigate the presence of $b / a_{\mathrm{IMP}} b / a_{\mathrm{VIM}^{\prime}} b / a_{\mathrm{GIM}^{\prime}} b / a_{\mathrm{SIM}}$ and $b / a_{\mathrm{SPM}}$ genes, which are responsible for MBL production. Clonal relationships among MBL-PA isolates were analyzed by pulsed-field gel electrophoresis. The patients' hospital records were retrospectively examined. Various demographic and clinical characteristics were evaluated in relation to MBL-PA.

Results: Thirty-two (9.6\%) of the carbapenem-resistant PA isolates were found to carry $b / a_{\mathrm{VIM}}$ and/or bla $a_{\mathrm{IMP}}$ with three strains harboring both bla $a_{\mathrm{VIM}}$ and $b / a_{\text {IMP. }}$ MBL-PA isolates were more resistant to aminoglycosides and quinolones. Eight Verona integron-encoded metallo-beta-lactamase-type MBL-PA isolates were found to be identical in adults, while several clonally-related clusters were observed among MBL-PA isolates in both the pediatric and adult inpatients. Compared to non-MBL carbapenem-resistant PA, the risk factors evaluated were found to have no association with MBL-PA. In addition, there was no statistically significant difference in mortality between patients from whom MBL-PA or non-MBL-PA was isolated.

Conclusion: Although MBL-PA has been implicated in various healthcare-related outbreaks, no specific risk factor has been identified in association with MBL-PA isolation. To our knowledge, this is the first study in Turkey to detect $P$. aeruginosa isolates carrying both b/a $a_{\mathrm{VIM}}$ and bla $a_{\mathrm{IMP}}$. Keywords: Pseudomonas aeruginosa, carbapenem resistance, metallo-beta-lactamase, $b / a_{\mathrm{IMP}}, b / a_{\mathrm{VIM}}$ pulsed-field gel electrophoresis

Giriş: Bu çalışmada metallo-beta-laktamaz üreten Pseudomonas aeruginosa (MBL-PA) suşlarının moleküler epidemiyolojik özelliklerinin belirlenmesi ve MBL-PA varlığının hasta mortalitesi ve morbiditesi ile ilişkisinin değerlendirilmesi amaçlandı.

Gereç ve Yöntem: Karadeniz Teknik Üniversitesi Tıp Fakültesi Hastanesi'nde 2009-2010 yıllarında bir, çeşitli klinik örneklerden izole edilmiş 334 karbapenem dirençli P. aeruginosa kökeni çalışmaya dahil edildi. Karbapenem dirençli PA izolatlarında MBL varlığı fenotipik olarak Modified Hodge ve imipenem/imipenem-etilen diamin tetra asetik asit kombine disk testleri ile araştırıldı. MBL üretiminden sorumlu genlerden olan $b / a_{\mathrm{IMP}}, b / a_{\mathrm{VIM}^{\prime}} b / a_{\mathrm{GIM}^{\prime}}$ $b / a_{\text {SIM }}$ ve $b / a_{\text {SPM }}$ genlerinin varlığı çoklu polimeraz zincir reaksiyonu yöntemi ile araştırıldı. MBL-PA olduğu belirlenen suşların klonal ilişkisi pulsedfield jel elektroforez ile analiz edildi. Hastaların tıbbi kayıtları geriye dönük olarak MBL-PA ile ilişkisi açısından incelendi. Metallo-beta-laktamaz üreten Pseudomonas aeruginosa ve non-MBL-PA izole edilen hastaların çeşitli demografik ve klinik özellikleri istatistiksel olarak değerlendirildi. Bulgular: Karbapenemlere dirençli PA suşlarının 32'sinde $(\% 9,6) b / a_{\mathrm{VIM}}$ ve/veya bla ${ }_{\text {IMP }}$ olumlu saptandı. Bunların üç tanesinin aynı anda bla $a_{\mathrm{VIM}}$ ve bla $a_{\text {IMP }}$ geni taşıdığı tespit edildi. MBL-PA suşlarının aminoglikozidlere ve kinolonlara direnç oranlarının daha yüksek olduğu görüldü. Erişkinlerde

Cite this article as: Beşli Y, Bayramoğlu G, Tosun İ, Kaklıkkaya N, Aydın F. Molecular Epidemiology and Clinical Characteristics of Metallo-beta-lactamase Producing Pseudomonas aeruginosa Isolates. Mediterr J Infect Microb Antimicrob. 2018;7:30. 
saptanan VIM tipi MBL üreten PA suşlarından sekizinin identik olduğu görüldü ve gerek erişkin gerekse çocuk hastalardan izole edilen MBL-PA'lar arasında klonal kümelenmeler saptandı. Karbapenem dirençli PA izole edilenler hastalardan, MBL-PA ve non-MBL-PA grupları arasında incelenen risk faktörleri ve mortalite açısından fark bulunmamıştır.

Sonuç: Metallo-beta-laktamaz üreten Pseudomonas aeruginosa izolasyonu ile ilişkili özellikli bir risk faktörü saptanmamış olsa da MBL-PA'nın sağlık bakımı kaynaklı çeşitli salgınlara neden olduğu gösterilmiştir. Ayrıca bildiğimiz kadarıyla çalışmamız, Türkiye'de bla $a_{\mathrm{VIM}}$ ve bla $a_{\text {IMP }}$ genlerinin aynı anda saptandığı PA izolatlarını rapor eden ilk çalışmadır.

Anahtar Kelimeler: Pseudomonas aeruginosa, karbapenem direnci, metallo-beta-laktamaz, bla ${ }_{\mathrm{IMP}^{\prime}}$ bla $_{\mathrm{VII}^{\prime}}$ pulsed-field jel elektroforez

\section{Introduction}

Metallo-beta-lactamase-producing Pseudomonas aeruginosa (MBL-PA) is a microorganism of crucial importance. It is resistant to all beta-lactam antibiotics except monobactams ${ }^{[1]}$. Metallo-beta-lactamases identified in carbapenem-resistant $P$. aeruginosa include imipenemase (IMP), Verona integronencoded metallo-beta-lactamase (VIM), São Paulo metallobeta-lactamase (SPM), Germany imipenemase (GIM), New Delhi metallo-beta-lactamase, and Florence imipenemase ${ }^{[2]}$. These MBL genes are carried by specific plasmids, along with other genes encoding regions responsible for resistance to carbapenems and other antibiotics. Therefore, MBL-PA isolates are usually multidrug-resistant, and these genetic elements also cause increased resistance since resistance can be transferred to other Gram-negative species ${ }^{[1]}$.

There is a need to assess the current epidemiological status of MBL-PA in the local setting and to delineate the mechanisms which lead to resistance. By precisely determining the clinical and molecular characteristics of the isolates involved, we may better understand their epidemiology, since these characteristics form the basis for effective epidemiological surveillance. The surveillance in turn helps us to gauge the effectiveness of infection control measures and to guide correctly targeted and timely treatment measures ${ }^{[1-3]}$. According to the hitherto limited research conducted in this field in Turkey, VIM-type MBLs are the most commonly reported $\mathrm{MBL}$ types in $P$. aeruginosa isolates ${ }^{[3-8]}$. More comprehensive research on this subject is required to reveal the absolute epidemiology of resistance and the clinical and molecular characteristics of MBL-PA in Turkey ${ }^{[3]}$.

In order to assess the molecular epidemiology in terms of dissemination of MBL-PA isolates and the clinical characteristics related to MBLs in our hospital, we aimed to detect MBL-PA isolates, demonstrate the molecular epidemiology of MBL-PA, and determine any clinical risk factors associated with MBL-PA and the clinical outcomes of MBL-PA isolation among inpatients.

\section{Materials and Methods}

\section{Study Design}

This single-center retrospective study was conducted at Karadeniz Technical University Faculty of Medicine Hospital, a 900- bed university hospital in Trabzon, Turkey. A non-duplicate carbapenem-resistant $P$. aeruginosa strain from each patient was included to the study. If $>1$ isolates were obtained from a single patient, only the first isolate was included the study. Carbapenem-resistant isolates (intermediate or resistant to imipenem and/or meropenem) had been previously isolated from a total of 356 patients in 2009-2010, and the 334 samples that could be recovered from the frozen stocks were included in this study. All isolates were stored at $-80{ }^{\circ} \mathrm{C}$ in cryopreservation vials (Thermo Scientific, USA) until analysis with Modified Hodge test (MHT), imipenem/imipenemethylene diamine tetra acetic acid (EDTA) combined disc test (CDT), and molecular tests.

Medical records of the patients were retrospectively reviewed. Hence, owing to the retrospective nature of this part of the study, it was not deemed necessary to obtain written consent from the patients. Due to inadequacy of the patients' hospital records, it could not be ascertained whether the $P$. aeruginosa isolates represented colonization or were the causative agents of an infection.

Phenotypic investigation of $\mathrm{MBL}$ producers was performed by both the MHT and the imipenem/imipenem-EDTA CDT. Multiplex polymerase chain reaction (PCR) was performed to investigate carriage of the $b / a_{\mathrm{IMP}} b / a_{\mathrm{VIM}^{\prime}} b / a_{\mathrm{GIM}^{\prime}} b / a_{\mathrm{SIM}}$ and $b / a_{\mathrm{SPM}}$ genes. The molecular epidemiology and microbiological characteristics of the MBL-PA isolates were evaluated in two groups: a pediatric inpatient group and an adult inpatient group.The genetic relatedness of carbapenem-resistant MBL-PA isolates was investigated by pulsedfield gel electrophoresis (PFGE) for each group ${ }^{[13-18]}$.

\section{Retrospective Case-Control Study}

A retrospective case-control study was performed to evaluate risk factors related to MBL-PA. The risk factors analyzed were: age, sex, underlying diseases, comorbidities, source of the carbapenem-resistant $P$. aeruginosa isolate, previous surgical operations, invasive device usage (central venous catheter, endotracheal tube, and urinary catheter), mechanical ventilation, immunosuppression lasting longer than 14 days (e.g. chemotherapy, corticoids), and antimicrobial usage (for at least $48 \mathrm{~h}$ over the preceding 14 days). A total of 158 patients (from a potential 334 patients) with available hospital records were retrospectively reviewed 
from the pediatric $(n=23)$ and adult $(n=135)$ inpatient groups. Outpatients $(n=42)$ were excluded from the risk assessment and the clinical outcome evaluation. Patients whose samples yielded MBL-PA were defined as the case group, while the patients with non-MBL-PA isolates were defined as the control group. Clinical outcome was assessed based on the length of hospital stay and whether the final outcome was discharge or death. MB-PA-related mortality was defined as death occurring within ten days of MBL-PA being isolated ${ }^{[9,10]}$.

\section{Bacterial Identification and Susceptibility Tests}

Identification and susceptibility testing of the isolates was performed using standard laboratory methods and Phoenix NMIC/ID-55 panels (Becton Dickinson Bioscience automatic system; USA) in accordance with the manufacturer's instructions. P. aeruginosa ATCC 27853 was used as a quality control strain. Antimicrobial susceptibility test results were interpreted according to the recommendations of the Clinical and Laboratory Standards Institute ${ }^{[11]}$.

\section{Modified Hodge Test}

A suspension of Escherichia coli ATCC 25922 was inoculated on a Mueller-Hinton agar after the density was adjusted to McFarland 0.5 standard, after which a $10-\mu \mathrm{g}$ imipenem disc (Oxoid Thermo Fisher, UK) was placed at the center of the agar plate. The test isolates, positive control strain (Klebsiella pneumoniae ATCC BAA-1705), and negative control strain (K. pneumoniae ATCC BAA-1706) were streaked in a straight line from the edge of the disc to the edge of the plate, in different directions for each isolate. In case of E. coli ATCC 25922 growth on the test isolate streak line towards the imipenem disc after overnight incubation, the so-called "clover leaf" pattern, the test isolate was interpreted as MHTpositive $^{[11]}$.

\section{Imipenem/Imipenem-Ethylene Diamine Tetra Acetic Acid Combined Disc Test}

Suspensions of the test isolates and control strains were inoculated on Mueller-Hinton agar after adjusting the density to McFarland 0.5 standard. Two 10- $\mu \mathrm{g}$ imipenem discs (Oxoid Thermo Fisher, UK) were placed on the agar plate with a distance of $20 \mathrm{~mm}$ between their centers. Ten $\mu \mathrm{L}$ of $0.5 \mathrm{M}$ EDTA was added onto one of the imipenem discs. After overnight incubation, the discs were examined. If the zone of inhibition surrounding the disc impregnated with both imipenem and EDTA was at least 7 $\mathrm{mm}$ greater in size than the zone around the disc containing imipenem alone, the isolate was considered MBL-positive ${ }^{[12]}$. IMP-positive 587585 P. aeruginosa and VIM-positive 670448 $P$. aeruginosa isolates, which Ozgumus et al. ${ }^{[5]}$ reported to be producers of MBL, were used as positive controls, while $P$. aeruginosa ATCC 27853 was used as a negative contro[ ${ }^{[5]}$.

Polymerase Chain Reaction Detection of Metallo-betalactamase Genes

Bacterial DNA was extracted by the boiling method ${ }^{[13]}$. Polymerase chain reaction was performed using a bacterial DNA template together with the specific primers listed in Table $1^{[14,15]}$. IMP-positive 587585 P. aeruginosa and VIMpositive $670448 P$. aeruginosa isolates were used as positive controls. P. aeruginosa ATCC 27853 and distilled water were used as negative controls ${ }^{[5]}$. For the $b / a_{\mathrm{IMP}}(\mathrm{A}), b / a_{\mathrm{VIM}}(\mathrm{A}), b / a_{\mathrm{GIM}}$, $b / a_{\mathrm{SIM},}$ and $b / a_{\mathrm{SPM}}$ genes, the PCR amplification conditions were as follows: initial DNA denaturation at $94{ }^{\circ} \mathrm{C}$ for $5 \mathrm{~min}$,

Table 1. List of primers used in this study[14,15]

\begin{tabular}{|c|c|c|c|c|}
\hline \multicolumn{2}{|l|}{ Primer } & \multirow{2}{*}{\begin{tabular}{|l|} 
Sequence $\left(\mathbf{5}^{\prime}-\mathbf{3}^{\prime}\right)$ \\
GAATAG(A/G)(A/G)TGGCTTAA(C/T)TCTC \\
\end{tabular}} & \multirow{3}{*}{\begin{tabular}{|l} 
Amplicon size (bp) \\
188
\end{tabular}} & \multirow{3}{*}{\begin{tabular}{|l} 
Reference \\
14
\end{tabular}} \\
\hline \multirow{2}{*}{$b / a_{\mathrm{IMP}}(\mathrm{A})$} & $\mathrm{F}-1$ & & & \\
\hline & R-1 & CCAAAC(C/T)ACTA(G/C)GTATC & & \\
\hline \multirow{2}{*}{$b / a_{\mathrm{IMP}}(\mathrm{B})$} & $\mathrm{F}-2$ & ATG AGC AAG TTA TCT TAG TAT TC & \multirow{2}{*}{765} & \multirow{2}{*}{15} \\
\hline & R-2 & GCT GCA ACG GAC TG TTA G & & \\
\hline \multirow{2}{*}{$b / a_{\mathrm{VIM}}(\mathrm{A})$} & $\mathrm{F}-3$ & GITGGTCGCATATCGCAAC & \multirow{2}{*}{382} & \multirow{2}{*}{14} \\
\hline & R-3 & AATGCGCAGCACCAGGATAG & & \\
\hline \multirow{2}{*}{$b / a_{\mathrm{VIM}}(\mathrm{B})$} & $\mathrm{F}-4$ & AGT GGT GAG TAT CCGACA G & \multirow{2}{*}{261} & \multirow{2}{*}{15} \\
\hline & R-4 & ATG AAA GTG CGT GGA GAC & & \\
\hline \multirow{2}{*}{$b / a_{\mathrm{GIM}}$} & F-5 & TCAATAGCTCTTGGGCTGAC & \multirow{2}{*}{72} & \multirow{2}{*}{14} \\
\hline & R-5 & CGGAACGACCATTGAATGG & & \\
\hline \multirow{2}{*}{$b / a_{\mathrm{SIM}}$} & F-6 & GTACAAGGGATTCGGCATCG & \multirow{2}{*}{569} & \multirow{2}{*}{14} \\
\hline & R-6 & TGGCCTGTCCCATGTGAG & & \\
\hline \multirow{2}{*}{$b / a_{\mathrm{SPM}}$} & F-7 & CTAAATCGAGAGCCCTGCTTG & \multirow{2}{*}{798} & \multirow{2}{*}{14} \\
\hline & R-7 & CCTITCCGCGACCTGATC & & \\
\hline
\end{tabular}


followed by 35 cycles of denaturation at $94{ }^{\circ} \mathrm{C}$ for $20 \mathrm{sec}$, annealing at $53{ }^{\circ} \mathrm{C}$ for $45 \mathrm{sec}$, and extension at $72{ }^{\circ} \mathrm{C}$ for 30 sec, followed by final extension at $72{ }^{\circ} \mathrm{C}$ for $6 \min ^{[16]}$. For the $b / a_{\mathrm{IMP}}(\mathrm{B})$ and $b / a_{\mathrm{VIM}}$ (B) genes, PCR amplification was done using the following conditions: initial DNA denaturation at $94^{\circ} \mathrm{C}$ for $5 \mathrm{~min}$, followed by 35 cycles of denaturation at 94 ${ }^{\circ} \mathrm{C}$ for $25 \mathrm{sec}$, annealing at $57^{\circ} \mathrm{C}$ for $40 \mathrm{sec}$, and extension at $72{ }^{\circ} \mathrm{C}$ for $50 \mathrm{sec}$, followed by final extension at $72{ }^{\circ} \mathrm{C}$ for 6 $\min ^{[15]}$.

\section{Pulsed-field Gel Electrophoresis}

Chromosomal DNA was prepared as previously described. Spel (Promega Corp., USA) was used to digest the genomic DNA. Lambda phage concatemers (Bio-Rad Laboratories, USA) were used as a size marker. Electrophoresis was carried out under the following conditions using the CHEF-DR III system (Bio-Rad Laboratories, USA): an initial switch time of 5 seconds, final switch time of 35 seconds, gradient of $6 \mathrm{~V} / \mathrm{cm}$, and included angle of $120^{\circ}$ for a 24-hour run ${ }^{[17]}$. Bio-Rad Gel Doc System (Bio-Rad Laboratories, USA) was utilized to document the PGFE patterns, and the clonal relationship among isolates was analyzed by Molecular Analyst Software (Bio-Rad Laboratories, USA) using the Dice similarity coefficient. Isolates with $\geq 95 \%$ genetic similarity in PFGE profiles were defined as being from the same clone, while clusters were defined as DNA patterns with $\geq 85 \%$ similarity ${ }^{[18]}$.

\section{Statistical Analyses}

The SPSS 13.0 program (SPSS Inc., USA) was used for all statistical analyses. The Kolmogorov-Smirnov (K-S) test was used to determine normality. For binomial comparisons of numerical data, Student's t-test was used for normal distributions and the Mann-Whitney $U$ test was used for nonnormal distributions. The independent-samples t-test was used to compare means of the data. The $\chi^{2}$ test was used for qualitative comparisons. The Kaplan-Meier test was used for survival analysis. Statistical tests with $p<0.05$ were considered statistically significant.

\section{Results}

Detection of Metallo-beta-lactamase-producing $P$. aeruginosa Isolates

The evaluation of MHT and CDT in the detection of MBL-PA isolates is summarized in Table 2. The $b / a_{\mathrm{VIM}}(\mathrm{A})$ and $b / a_{\mathrm{IMP}}(\mathrm{A})$ primer sets were more effective for PCR detection of VIM- and IMP-type MBL genes. However, the strains used as positive controls (IMP-positive 587585 P. aeruginosa, and VIMpositive 670448 isolates $P$. aeruginosa) were positive when using either of the specific primer sets (Table 3). The $b / a_{\mathrm{SPM}^{\prime}}$ $b / a_{\text {SIM }}$ and $b / a_{\text {GIM }}$ genes were not found in any of the 334 $P$. aeruginosa isolates.

Table 2. Evaluation of Modified Hodge test and imipenem/imipenem-ethylene diamine tetra acetic acid combined disc test for detection of metallo-beta-lactamase-producing Pseudomonas aeruginosa isolates

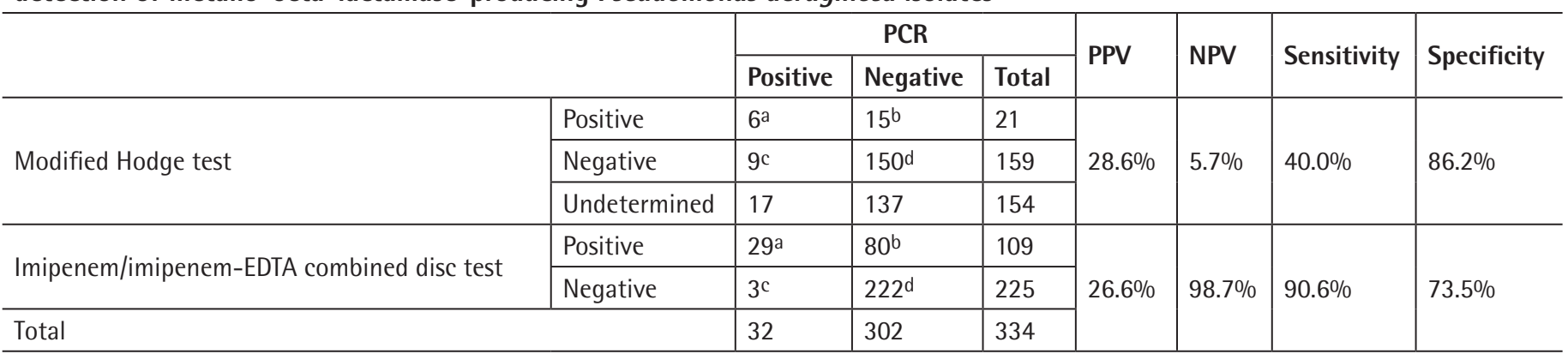

PCR: Polymerase chain reaction for detection of $b / a_{I M P}, b / a_{V I M}, b / a_{G I M}, b l a_{S I M}$ and $b / a_{S P M}$, PPV: Positive predictive value, NPV: Negative predictive value, EDTA: Ethylene diamine tetra acetic acid, a Number of true positive isolates, ${ }^{b}$ Number of false positive isolates, ${ }^{\mathrm{C}}$ Number of false negative isolates, ${ }^{\mathrm{d}}$ Number of true negative isolates

Table 3. Polymerase chain reaction detection of $b / a_{\mathrm{VIM}}$ and $b / a_{\mathrm{IMP}}$ genes regions using different specific primers

\begin{tabular}{|c|c|c|c|c|}
\hline \multirow{2}{*}{ Primer } & \multirow{2}{*}{ Amplificon size } & \multicolumn{3}{|l|}{ Positive isolates } \\
\hline & & Isolate code & $\mathbf{n}$ & $(\%)$ \\
\hline$b / a_{\mathrm{VIM}}(\mathrm{A})$ & 382 bp & $\begin{array}{l}\text { PA14, PA19, PA43, PA143, PA146, PA152, PA156, PA170, PA206, PA230, PA236, PA237, PA238, } \\
\text { PA240, PA241, PA254, PA259, PA272, PA277, PA282, PA298, PA306, PA328 }\end{array}$ & 23 & 6.9 \\
\hline$b / a_{\mathrm{VIM}}(\mathrm{B})$ & $261 \mathrm{bp}$ & PA14, PA19, PA170, PA206, PA237, PA254 & 6 & 1.8 \\
\hline$b / a_{\mathrm{IMP}}(\mathrm{A})$ & $188 \mathrm{bp}$ & PA31, PA33, PA35, PA136, PA139, PA140, PA143, PA145, PA146, PA156, PA157, PA166 & 12 & 3.6 \\
\hline
\end{tabular}

bp: base pair. n: number 


\section{Microbiological Characteristics of Carbapenem-resistant} $P$. aeruginosa Isolates

Carbapenem-resistant $P$. aeruginosa organisms were isolated from several clinical specimens: 165 (49.4\%) were isolated from respiratory tract samples, 63 (18.9\%) from genitourinary system samples, $59(17.6 \%)$ from skin and soft tissue samples, $28(8.4 \%)$ from blood samples, and 19 (5.7\%) from other samples.

Carbapenemase production was detected by MHT in 21 (6.3\%) of the 334 P. aeruginosa isolates. MBL production was found in 109 (32.6\%) isolates with CDT (Table 2). Among 334 carbapenem-resistant $P$. aeruginosa isolates, 32 (9.6\%) were positive for $b / a_{\mathrm{VIM}}$ or/and $b / a_{\mathrm{IMP}}$ and 3 of these isolates were harboring both $b / a_{\mathrm{VIM}}$ and $b / a_{\mathrm{IMP}}$ (Table 3).

Eight of the MBL-PA were isolated from pediatric inpatients. Three of them were $b / a_{\mathrm{VIM}}$-positive, four were bla ${ }_{\mathrm{IMP}}$-positive, and one was both $b / a_{\mathrm{VIM}}{ }^{-}$and bla $a_{\mathrm{IMP}}$-positive. Among P. aeruginosa isolates found to be MBL-positive, 17 were isolated from the adult inpatient group, of which 13 were VIM-positive only and four were IMP-positive only. Seven of the MBL-PA were isolated from outpatients, of which four were $b / a_{\mathrm{VIM}}$-positive, one was bla $a_{\mathrm{IMP}}$-positive, and two were found to be positive for both $b / a_{\mathrm{VIM}}$ and $b / a_{\mathrm{IMP}}$.
Antibiotic resistance patterns of the carbapenem-resistant $P$. aeruginosa isolates are summarized in Graphic 1. Compared to non-MBL-PA, MBL-PA isolates showed higher rates of resistance for antibacterial agents such as piperacillin, ceftazidime, cefepime, piperacillin-tazobactam, aztreonam, gentamicin, amikacin, and ciprofloxacin.

Molecular Epidemiology of Metallo-beta-lactamase-producing $P$. aeruginosa Isolates in the Pediatric Inpatient Group

All the $b / a_{\mathrm{VIM}}$ or/and $b / a_{\mathrm{IMP}}$-harboring PA strains $(\mathrm{n}=8)$ isolated from the pediatric inpatient group were compared by PFGE. Three different pulsotypes were obtained among the isolates of PA harboring $b / a_{\mathrm{VIM}}(\mathrm{n}=3)$ and PA harboring $b / a_{\mathrm{VIM}}$ and $b / a I_{\mathrm{MP}}(\mathrm{n}=1)$, while five different pulsotypes were obtained from isolates of PA harboring $b / a_{I M P}(n=4)$ and PA harboring $b / a_{\mathrm{VIM}}$ and $b / a_{\mathrm{IMP}}(\mathrm{n}=1)$ (Table 4). Three particular bla $a_{\mathrm{VIM}}$-harboring PA isolates (PA206, PA14, and PA19) were considered to form a cluster, with similarity over $85 \%$. Furthermore, two of them (PA14, and PA19) were effectively identical, with similarity over 95\%. With similarity over $85 \%$, two bla $a_{\text {MP }}$-harboring PA isolates (PA31, and PA35) were considered as a cluster, whereas a $b / a_{I \mathrm{MP}}$-harboring PA isolate (PA140) and the $b / a_{\mathrm{VIM}}$ and $b / a_{\mathrm{IMP}}$-harboring PA isolate (PA146) were defined as another cluster.

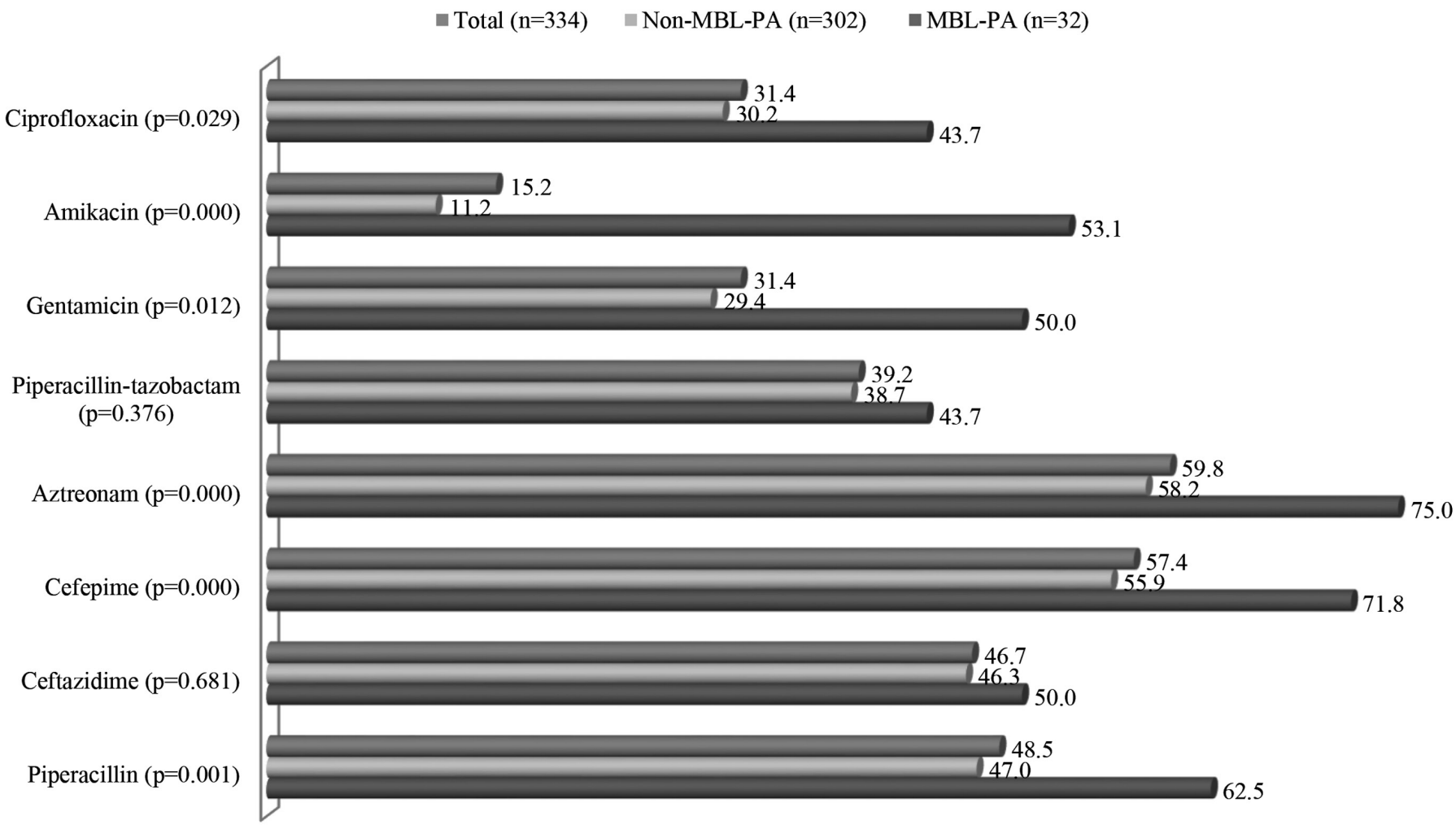

Graphic 1. Evaluation of antibiotic resistance rates (\%) of metallo-beta-lactamase-producing Pseudomonas aeruginosa and nonmetallo-beta-lactamase-producing Pseudomonas aeruginosa

MBL-PA: Metallo-beta-lactamase-producing Pseudomonas aeruginosa 
Molecular Epidemiology of Metallo-beta-lactamase-producing $P$. aeruginosa Isolates in the Adult Inpatient Group

All bla $a_{\mathrm{VIM}}$ or b/a $a_{\mathrm{IMP}}$-harboring PA isolates $(n=17)$ isolated from adult inpatients were compared by PFGE (Table 5). Six different pulsotypes were obtained in $b / a_{\text {VIM }}$-harboring PA $(n=13)$, while four different pulsotypes were obtained in bla ${ }_{\mathrm{IMP}}$-harboring PA $(=4)$. Eleven b/a ${ }_{\mathrm{VIM}}$-harboring PA isolates (PA230, PA237, PA250, PA282, PA238, PA254, PA43, PA328, PA241, and PA236) were considered a cluster, with over 85\% similarity. In addition, eight of those strains (PA282, PA238, PA298, PA254, PA43, PA328, PA241, and PA236) were identical, with similarity exceeding 95\%. Pulsotypes obtained from b/a $a_{\mathrm{IMP}}$-harboring PA isolates (PA166, PA139, PA145, and PA136) were less than $75 \%$ similar.
Clinical Characteristics of Metallo-beta-lactamase-producing $P$. aeruginosa Isolates

From a total of 334, 158 patients' hospital records were available. Of these, MBL-PA was isolated from 16 patients and non-MBL-PA was isolated from 142 (Figure 1). No statistical difference was found between patients with MBL-PA and those with non-MBL-PA in terms of age, gender, stay in the intensive care unit (ICU), length of stay in hospital before infection, site of infection, whether or not the infection was polymicrobial, presence of any other accompanying infection, underlying disease, or invasive procedure, history of surgery or trauma, hospitalization within the last 30 days, length of hospital stay, administration of antibiotherapy, or immunosuppressive therapy (Table 6$)$. Nine (43.8\%) of the patients with MBL-PA

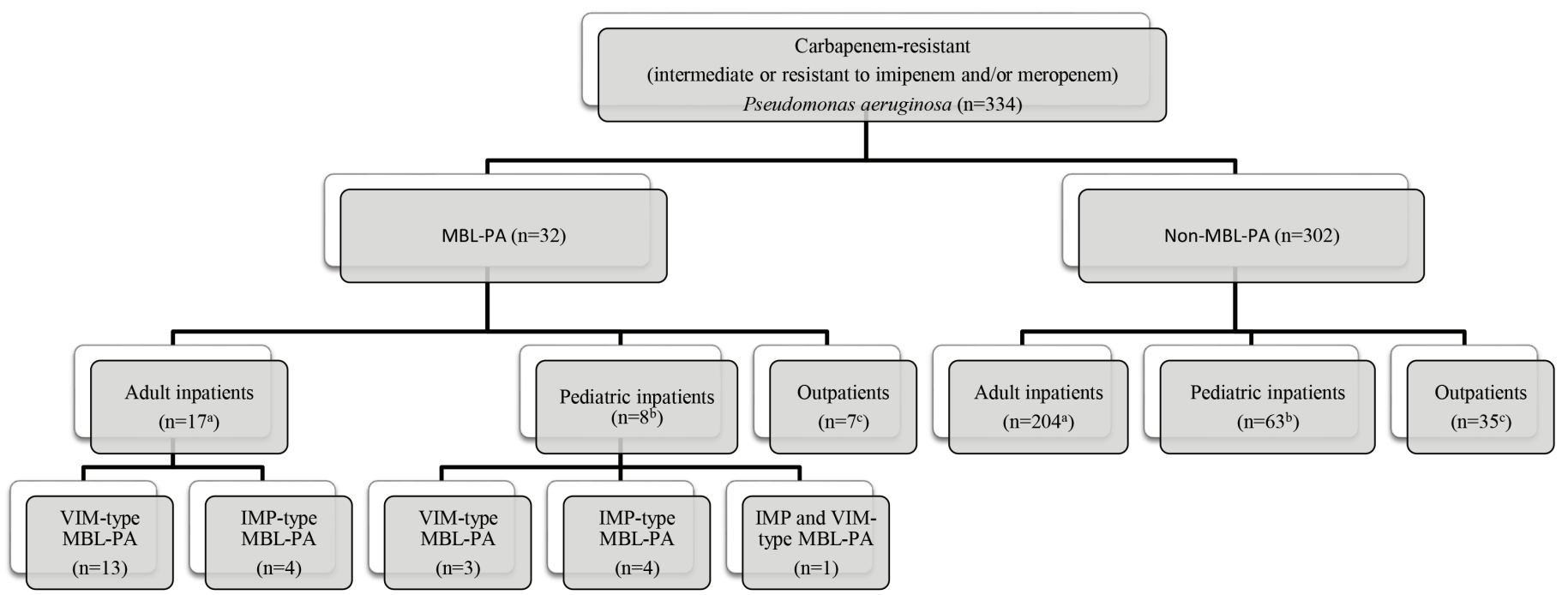

Figure 1. Summary of study findings for MBL-PA and non-MBL-PA

aOf 221 adult inpatients, hospital records were available for 135 patients, 11 of whom had MBL-PA isolates and 124 with non-MBL-PA isolates. b0f 71 pediatric inpatients, hospital records were available for 23 patients, 5 of whom had MBL-PA isolates and 18 with nonMBL-PA isolates. cA total of 42 outpatients were excluded from the PFGE analysis, risk assessment, and clinical outcome evaluation.

MBL-PA: Metallo-beta-lactamase-producing Pseudomonas aeruginosa, PFGE: Pulsed-field gel electrophoresis, IMP: P. aeruginosa include imipenemase, VIM: Verona integron-encoded metallo-beta-lactamase

Table 4. Pulsed-field gel electrophoresis patterns of the b/a $a_{\mathrm{VIM}}$-positive Pseudomonas aeruginosa and bla $a_{\mathrm{IMP}}-$ positive Pseudomonas aeruginosa isolates in the pediatric inpatient group

\begin{tabular}{|c|c|c|c|c|c|}
\hline Isolate code & Hospital unit & Source & Month/year of isolation & MBL type & PFGE pattern \\
\hline PA140 & Neonatal ICU & Tracheal aspirate & 02/2009 & $b / a_{\mathrm{IMP}}$ & $\mathrm{A} 1$ \\
\hline PA146 & Pediatric Ward & Urine & $03 / 2009$ & $b / a_{\mathrm{VIM}}$ and $b / a_{\mathrm{IMP}}$ & $\mathrm{A} 2$ \\
\hline PA206 & Pediatric Ward & Tracheal aspirate & $08 / 2009$ & $b / a_{\mathrm{VIM}}$ & B1 \\
\hline PA14 & Pediatric Ward & Tracheal aspirate & $02 / 2010$ & $b / a_{\mathrm{VIM}}$ & B2 \\
\hline PA19 & Pediatric Ward & Tracheal aspirate & $02 / 2010$ & $b / a_{\mathrm{VIM}}$ & B2 \\
\hline PA33 & Pediatric ICU & Tracheal aspirate & $04 / 2010$ & $b / a_{\mathrm{IMP}}$ & $\mathrm{C}$ \\
\hline PA35 & Pediatric ICU & Tracheal aspirate & $04 / 2010$ & $b / a_{\mathrm{IMP}}$ & D1 \\
\hline PA31 & Pediatric ICU & Tracheal aspirate & $04 / 2010$ & $b / a_{\mathrm{IMP}}$ & D2 \\
\hline
\end{tabular}

PFGE: Pulsed-field gel electrophoresis, ICU: Intensive care unit, MBL: Metallo-beta-lactamase 
Table 5. Pulsed-field gel electrophoresis patterns of the $b / a_{\mathrm{VIM}}$-positive Pseudomonas aeruginosa and $b \boldsymbol{a}_{\mathrm{IMP}}$-positive Pseudomonas aeruginosa isolates in the adult inpatient group

\begin{tabular}{l|l|l|l|l|l}
\hline Isolate code & Hospital unit & Source & Month/year of isolation & MBL type & PFGE pattern \\
\hline PA272 & Surgical ICU & Tracheal aspirate & $05 / 2008$ & $b / a_{\text {VIM }}$ & A \\
\hline PA306 & Surgical ICU & Tracheal aspirate & $10 / 2008$ & $b / a_{\text {VIM }}$ & B \\
\hline PA230 & Surgical ICU & Tracheal aspirate & $12 / 2009$ & $b / a_{\text {VIM }}$ & C1 \\
\hline PA237 & Neurology-Neurosurgery ICU & Tracheal aspirate & $01 / 2008$ & $b / a_{\text {VIM }}$ & C2 \\
\hline PA259 & Surgical ICU & Catheter & $05 / 2008$ & $b / a_{\text {VIM }}$ & C3 \\
\hline PA282 & Cardiology Ward & Urine & $07 / 2008$ & $b / a_{\text {VIM }}$ & C4 \\
\hline PA238 & Internal Medicine ICU & Urine & $01 / 2008$ & $b / a_{\text {VIM }}$ & C4 \\
\hline PA298 & Surgical ICU & Blood & $09 / 2008$ & $b / a_{\text {VIM }}$ & C4 \\
\hline PA254 & Neurology-Neurosurgery ICU & Tracheal aspirate & $04 / 2008$ & $b / a_{\text {VIM }}$ & C4 \\
\hline PA43 & Burn Unit & Burn & $05 / 2010$ & $b / a_{\text {VIM }}$ & C4 \\
\hline PA328 & Surgical ICU & Tracheal aspirate & $12 / 2008$ & $b / a_{\text {VIM }}$ & C4 \\
\hline PA241 & Plastic Surgery Ward & Wound & $02 / 2008$ & $b / a_{\text {VIM }}$ & C4 \\
\hline PA236 & Orthopedic Ward & Surgical material & $01 / 2008$ & $b / a_{\text {VIM }}$ & C4 \\
\hline PA166 & Surgical ICU & Catheter & $10 / 2009$ & $b / a_{\text {IMP }}$ & D \\
\hline PA139 & Neurology-Neurosurgery & Tracheal aspirate & $02 / 2009$ & $b / a_{\text {IIP }}$ & E \\
\hline PA145 & Internal Medicine ICU & Urine & $03 / 2009$ & $b / a_{\text {IMP }}$ & F \\
\hline PA136 & Plastic Surgery Ward & Wound & $02 / 2009$ & $b / a_{\text {IMP }}$ & $\mathrm{F}$ \\
\hline
\end{tabular}

PFGE: Pulsed-field gel electrophoresis, ICU: Intensive care unit, MBL: Metallo-beta-lactamase

Table 6. Statistical analysis of risk factors for metallo-beta-lactamase-producing Pseudomonas aeruginosa infections

\begin{tabular}{|c|c|c|c|c|c|c|}
\hline & & \multicolumn{2}{|c|}{ MBL-PA } & \multicolumn{2}{|c|}{ nonMBL-PA } & \multirow{2}{*}{$\mathrm{p}$ value } \\
\hline & & $\mathbf{n}$ & $\%$ & $\mathrm{n}$ & $\%$ & \\
\hline \multicolumn{2}{|l|}{ Age (years); Mean \pm SD } & \multicolumn{2}{|c|}{$37.1 \pm 29.4$} & \multicolumn{2}{|c|}{$47.9 \pm 25.4$} & 0.116 \\
\hline \multicolumn{2}{|c|}{ Length of hospital stay before PA isolation (days); Mean \pm SD } & \multicolumn{2}{|c|}{$33.3 \pm 34.9$} & \multicolumn{2}{|c|}{$23.3 \pm 20.9$} & 0.279 \\
\hline \multicolumn{2}{|c|}{ Duration of hospitalization after PA was isolated (days); Mean \pm SD } & \multicolumn{2}{|c|}{$32.3 \pm 24.5$} & \multicolumn{2}{|c|}{$24.9 \pm 41.2$} & 0.488 \\
\hline \multirow{2}{*}{ Group } & Pediatric & 5 & 3.2 & 18 & 11.4 & \multirow{2}{*}{0.610} \\
\hline & Adult & 11 & 78.5 & 124 & 78.5 & \\
\hline \multirow{2}{*}{ Sex } & Female & 3 & 1.9 & 52 & 32.9 & \multirow{2}{*}{0.850} \\
\hline & Male & 13 & 8.2 & 84 & 53.2 & \\
\hline \multirow{2}{*}{ Stay in ICU 48 hours before PA isolation } & No & 9 & 5.7 & 62 & 39.2 & \multirow{2}{*}{0.337} \\
\hline & Yes & 7 & 4.4 & 80 & 50.6 & \\
\hline \multirow{2}{*}{ Stay in ICU 48 hours after PA isolation } & No & 9 & 5.7 & 63 & 39.9 & \multirow{2}{*}{0.366} \\
\hline & Yes & 7 & 4.4 & 79 & 50.0 & \\
\hline \multicolumn{7}{|l|}{ Sample source } \\
\hline \multirow{2}{*}{ LRT } & Negative & 10 & 6.3 & 74 & 46.8 & \multirow{2}{*}{0.430} \\
\hline & Positive & 6 & 3.8 & 68 & 43.0 & \\
\hline \multirow{2}{*}{ UT } & Negative & 13 & 8.2 & 124 & 78.5 & \multirow{2}{*}{0.449} \\
\hline & Positive & 3 & 1.9 & 18 & 11.4 & \\
\hline \multirow{2}{*}{ Skin and soft tissue } & Negative & 12 & 7.6 & 119 & 75.3 & \multirow{2}{*}{0.480} \\
\hline & Positive & 4 & 2.5 & 23 & 14.6 & \\
\hline
\end{tabular}


Table 6. Continued

\begin{tabular}{|c|c|c|c|c|c|c|}
\hline & & \multicolumn{2}{|c|}{ MBL-PA } & \multicolumn{2}{|c|}{ nonMBL-PA } & \multirow{2}{*}{$p$ value } \\
\hline & & $\mathbf{n}$ & $\%$ & n & $\%$ & \\
\hline \multirow{2}{*}{ Blood } & Negative & 16 & 10.1 & 131 & 82.9 & \multirow{2}{*}{0.605} \\
\hline & Positive & 0 & 0.0 & 11 & 7.0 & \\
\hline \multirow{2}{*}{ Intra-abdominal } & Negative & 15 & 9.5 & 138 & 87.3 & \multirow{2}{*}{0.418} \\
\hline & Positive & 1 & 0.6 & 4 & 2.5 & \\
\hline \multirow{2}{*}{ Multisite } & Negative & 14 & 8.9 & 132 & 83.5 & \multirow{2}{*}{0.348} \\
\hline & Positive & 2 & 1.3 & 10 & 6.3 & \\
\hline \multirow{2}{*}{ Othera } & Negative & 16 & 10.1 & 134 & 84.8 & \multirow{2}{*}{1.000} \\
\hline & Positive & 0 & 0.0 & 8 & 5.1 & \\
\hline \multirow{2}{*}{ Polymicrobial growth } & Negative & 12 & 7.6 & 71 & 44.9 & \multirow{2}{*}{0.058} \\
\hline & Positive & 4 & 2.5 & 71 & 44.9 & \\
\hline \multirow{2}{*}{ Accompanying infection } & No & 10 & 6.3 & 66 & 41.8 & \multirow{2}{*}{0.224} \\
\hline & Yes & 6 & 3.8 & 76 & 48.1 & \\
\hline \multirow{2}{*}{ Sepsis or septic shock associated with PA } & No & 11 & 7.0 & 123 & 77.8 & \multirow{2}{*}{0.072} \\
\hline & Yes & 5 & 3.2 & 19 & 12.0 & \\
\hline \multicolumn{7}{|l|}{ Underlying disease } \\
\hline \multirow{2}{*}{ Any ( $\geq 1$ disease) } & Absent & 12 & 7.6 & 117 & 74.1 & \multirow{2}{*}{0.497} \\
\hline & Present & 4 & 2.5 & 25 & 15.8 & \\
\hline \multirow{2}{*}{ Pregnancy } & Absent & 16 & 10.1 & 140 & 88.6 & \multirow{2}{*}{1.000} \\
\hline & Present & 0 & 0.0 & 2 & 1.3 & \\
\hline \multirow{2}{*}{ Metabolic disease } & Absent & 14 & 8.9 & 134 & 84.8 & \multirow{2}{*}{0.268} \\
\hline & Present & 2 & 1.3 & 8 & 5.1 & \\
\hline \multirow{2}{*}{ Diabetes mellitus } & Absent & 14 & 8.9 & 128 & 81.0 & \multirow{2}{*}{0.667} \\
\hline & Present & 2 & 1.3 & 14 & 8.9 & \\
\hline \multirow{2}{*}{ Liver disease } & Absent & 15 & 9.5 & 136 & 86.1 & 0 \\
\hline & Present & 1 & 0.6 & 6 & 3.8 & 0.034 \\
\hline Ronalincuffipinnov & Absent & 13 & 8.2 & 116 & 73.4 & 1000 \\
\hline 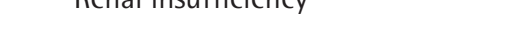 & Present & 3 & 1.9 & 26 & 16.5 & 1.000 \\
\hline Cordiovoccular dicences & Absent & 12 & 7.6 & 108 & 68.4 & 1000 \\
\hline Cardiovascular aiseases & Present & 4 & 2.5 & 34 & 21.5 & 1.000 \\
\hline Dulmonondisonest & Absent & 13 & 8.2 & 92 & 58.2 & \\
\hline rumonary aisedse & Present & 3 & 1.9 & 50 & 31.6 & 0.180 \\
\hline No maged dicos & Absent & 13 & 8.2 & 82 & 51.9 & \\
\hline theurutugical uisedse & Present & 3 & 1.9 & 60 & 38.0 & 0.005 \\
\hline & Absent & 14 & 8.9 & 118 & 74.7 & \\
\hline . & Present & 2 & 1.3 & 24 & 15.2 & 1.000 \\
\hline
\end{tabular}

Invasive procedure

\begin{tabular}{l|l|l|l|l|l|l}
\hline \multirow{2}{*}{ Any } & No & 4 & 2.5 & 27 & 17.1 \\
\cline { 2 - 7 } & Yes & 12 & 7.6 & 115 & 72.8 \\
\hline \multirow{2}{*}{ Central venous catheterization } & No & Yes & 11 & 7.0 & 99 & 62.7 \\
\cline { 2 - 7 } & 1.000 & 3.2 & 43 & 27.2 \\
\hline
\end{tabular}


Table 6. Continued

\begin{tabular}{|c|c|c|c|c|c|c|}
\hline & & \multicolumn{2}{|c|}{ MBL-PA } & \multicolumn{2}{|c|}{ nonMBL-PA } & \multirow{2}{*}{$p$ value } \\
\hline & & $n$ & $\%$ & $\mathbf{n}$ & $\%$ & \\
\hline \multirow{2}{*}{ Urinary catheterization } & No & 5 & 3.2 & 34 & 21.5 & \multirow{2}{*}{0.545} \\
\hline & Yes & 11 & 7.0 & 108 & 68.4 & \\
\hline \multirow{2}{*}{ Mechanical ventilation } & No & 7 & 4.4 & 48 & 30.4 & \multirow{2}{*}{0.428} \\
\hline & Yes & 9 & 5.7 & 94 & 59.5 & \\
\hline \multirow{2}{*}{ Total parenteral nutrition } & No & 10 & 6.3 & 121 & 76.6 & \multirow{2}{*}{0.034} \\
\hline & Yes & 6 & 3.8 & 21 & 13.3 & \\
\hline \multirow{2}{*}{ Hemodialysis } & No & 13 & 8.2 & 129 & 81.6 & \multirow{2}{*}{0.209} \\
\hline & Yes & 3 & 1.9 & 13 & 8.2 & \\
\hline \multirow{2}{*}{ Other invasive procedures $b$} & No & 12 & 7.6 & 118 & 74.7 & \multirow{2}{*}{0.488} \\
\hline & Yes & 4 & 2.5 & 24 & 15.2 & \\
\hline \multirow{2}{*}{ Hospitalization within the last 30 days } & No & 2 & 1.3 & 12 & 7.6 & \multirow{2}{*}{0.637} \\
\hline & Yes & 14 & 8.9 & 130 & 82.3 & \\
\hline \multirow{2}{*}{ Surgical operation within the last 30 days } & No & 8 & 5.1 & 83 & 52.5 & \multirow{2}{*}{0.517} \\
\hline & Yes & 8 & 5.1 & 59 & 37.3 & \\
\hline \multirow{2}{*}{ Trauma within the last 30 days } & No & 12 & 7.6 & 107 & 67.7 & \multirow{2}{*}{1.000} \\
\hline & Yes & 4 & 2.5 & 35 & 22.2 & \\
\hline \multirow{2}{*}{$\begin{array}{l}\text { Immunosuppressive therapy within the last } \\
30 \text { days }\end{array}$} & No & 14 & 8.9 & 87 & 55.1 & \multirow{2}{*}{0.038} \\
\hline & Yes & 2 & 1.3 & 55 & 34.8 & \\
\hline \multicolumn{7}{|l|}{ Antibiotherapy within the last 30 days } \\
\hline \multirow{2}{*}{ Use of any antibiotics } & No & 2 & 1.3 & 12 & 7.6 & \multirow{2}{*}{0.637} \\
\hline & Yes & 14 & 8.9 & 130 & 82.3 & \\
\hline \multirow{2}{*}{ Penicillins } & No & 13 & 8.2 & 119 & 75.3 & \multirow{2}{*}{0.729} \\
\hline & Yes & 3 & 1.9 & 23 & 14.6 & \\
\hline 1st/2nd a noretion conbelocnoring & No & 13 & 8.2 & 112 & 70.9 & 1000 \\
\hline pry ziu generation cepnarosporins & Yes & 3 & 1.9 & 30 & 19.0 & 1.000 \\
\hline 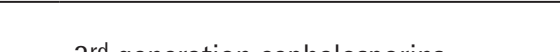 & No & 9 & 5.7 & 72 & 45.6 & \\
\hline $3^{\text {rd }}$ generation cephalosporins & Yes & 7 & 4.4 & 70 & 44.3 & 0.674 \\
\hline 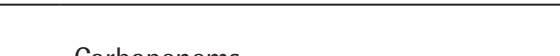 & No & 10 & 6.3 & 78 & 49.4 & 0502 \\
\hline Caroapenems & Yes & 6 & \begin{tabular}{|l|}
3.8 \\
\end{tabular} & 64 & 40.5 & 0.563 \\
\hline & No & 9 & 5.7 & 113 & 71.5 & \\
\hline Aminoglycosides & Yes & 7 & 4.4 & 29 & 18.4 & 0.055 \\
\hline O. & No & 14 & 8.9 & 126 & 79.7 & 1000 \\
\hline Uuinolones & Yes & 2 & 1.3 & 16 & 10.1 & 1.000 \\
\hline cYT & No & 14 & 8.9 & 130 & \begin{tabular}{|l|}
82.3 \\
\end{tabular} & 0627 \\
\hline SXI & Yes & 2 & 1.3 & 12 & 7.6 & 0.631 \\
\hline Tigecycline & No & 16 & 10.1 & 128 & 81.0 & 0364 \\
\hline ligecyclıne & Yes & 0 & 0.0 & 14 & 8.9 & 0.364 \\
\hline
\end{tabular}

MBL-PA: Metallo-beta-lactamase-producing Pseudomonas aeruginosa, nonMBL-PA: Non-metallo-beta-lactamase-producing Pseudomonas aeruginosa, n: Number of patients, Mean: arithmetic mean, SD: Standard deviation, LRT: Lower respiratory tract, UT: Urinary tract, SXT: Trimethoprim-sulfamethoxazole, a: Ear, conjunctiva, vagina, b: Ventriculoperitoneal shunt, chest tube, nephrostomy, colostomy, peritoneal dialysis catheter 
died, while $70(50.7 \%)$ of the patients with non-MBL-PA died. No significant difference was found between patients with MBL-PA and non-MBL-PA in terms of mortality (Log Rank: 0.536, $p=0.384$ ).

\section{Discussion}

MBL-PA is a critical pathogen due to its pathogenicity and antimicrobial resistance characteristics. In order to prevent and manage infections caused by MBL-PA, studies focused on epidemiology, mechanisms of antimicrobial resistance, antimicrobial stewardship, clinical risk factors for MBL-PA infection, and the development of diagnostic tools for rapid detection of MBL-PA are needed ${ }^{[2]}$. In the present study, approximately $9.6 \%$ (32/334) of the carbapenem-resistant PA were found to be $b / a_{\mathrm{VIM}}$ and/or b/a $a_{\mathrm{IMP}}$-positive, and three of them carried both of the bla $\mathrm{VII}_{\text {I }}$ and bla $\mathrm{I}_{\mathrm{IMP}}$ genes. Different clonally related clusters were identified among MBL-PA isolates in the pediatric inpatient group as well as in the adult inpatient group by PFGE fingerprinting. In addition, eight of the MBL-PA strains isolated from adult inpatients were found to be from the same clone. Comparing carbapenem-resistant $P$. aeruginosa isolates with non-MBL-PA isolates, higher resistance rates were observed in the MBL-PA isolates.

Carbapenemases are responsible for an important part of carbapenem resistance and are a source of concern worldwide. Various types of carbapenemases have been increasingly reported in $P$. aeruginosa strains over the years ${ }^{[2,3,19,20]}$. The distribution of carbapenemases varies according to geographical region, but the most prevalent MBL enzyme types are VIM and $\mathrm{IMP}^{[2]}$. Verona integron-encoded metallo-beta-lactamase-type MBLs in $P$. aeruginosa have been the most commonly reported carbapenemases in Turkey to date, whereas $P$. aeruginosa producing IMP-type MBLs have only been reported from Trabzon and Muş ${ }^{[3-8]}$. Include imipenemase-type MBLs have not yet been reported in Enterobacteriaceae or Acinetobacter baumannii isolates in Turkey ${ }^{[21-25]}$. In the present study, 32 MBL-PA were detected among 334 carbapenem resistant $P$. aeruginosa isolates (9.6\%), and bla ${ }_{\mathrm{VIM}}$ was more prevalent than $b / a_{\mathrm{IMP}}$. Additionally, considering that our study was conducted at the same hospital from which the first IMP-type MBL was detected, additional studies should be performed in different regions of the country in order to ascertain whether the VIMtype MBLs are limited to these regions ${ }^{[5-8]}$. Our study appears to be the first from Turkey reporting PA isolates with both $b / a_{\mathrm{VIM}}$ and $b / a_{\mathrm{IMP}}$ carriage.

Compared with non-MBL-PA isolates, MBL-PA isolates were found to be more resistant to aminoglycosides, quinolones, and even aztreonam in this study. Although aztreonam is not a substrate for MBLs, it is often ineffective against these strains due to additional mechanisms of resistance ${ }^{[1,26]}$.
Additional resistance mechanisms in MBL-PA commonly include cephalosporinase, efflux pumps, or low intrinsic outer membrane permeability. Furthermore, MBL genes and genes encoding other antibiotic resistance determinants may be located on the same plasmids ${ }^{[27]}$. Therefore, additional resistance mechanisms could be acquired simultaneously with MBL genes and lead to resistance to antibiotics other than beta-lactams such as aminoglycosides and quinolones ${ }^{[1,26]}$. Depending on the factors listed, it is possible to detect high resistance rates and multidrug resistance in MBL-PA isolates, as demonstrated by this study.

PFGE analysis demonstrated several clonally-related genotype clusters among the VIM-type MBL-PA and IMP-type MBL-PA isolates in the pediatric inpatient group, while eight of the VIM-type MBL-PA isolates from the adult inpatient group were identical. These findings indicate that cross-transmission is an important mechanism for dissemination of MBL-PA, resulting in multidrug resistance in $P$. aeruginosa isolates.

Potential risk factors identified for infection or colonization with MBL-PA include ICU stay, long-term hospitalization, use of indwelling urinary catheters, urinary tract diseases, hemodialysis, and hospitalization within the preceding year, administration of antineoplastic agents or corticosteroids, fluoroquinolone usage, and long-term antibiotic use (especially beta-lactams) ${ }^{[9,28-31]}$. Nonetheless, we found no statistically significant difference between MBL-PA and non-MBL-PA in terms of demographic features, stay in ICU, length of hospital stay before isolation, sample source, underlying disease, invasive procedure, or history of antibiotic therapy, hospitalization, surgery, trauma, or immunosuppressive therapy within the last 30 days. While some researchers have reported that $\mathrm{MBL}-\mathrm{PA}$ infections result in a higher mortality rate than non-MBL-PA infection, others have found no association between MBL-PA and mortality ${ }^{[28,30,31]}$. We also found no statistically significant differences in terms of mortality. This finding may be because of our limited data about the patients. Differences of mortality rates may also be related to the virulence properties of the infecting strains.

One of the limitations of this study is that because of its retrospective design, records were not available for all patients. In addition, the MBL-PA groups were significantly smaller in number than the non-MBL-PA groups due to the prevalence of MBLs.

\section{Conclusion}

$\mathrm{MBL}-\mathrm{PA}$ isolates are more resistant than non-MBL-PA, and the high clonality among the MBL-PA strains indicates that crosstransmission is an important mechanism of dissemination for MBL-PA isolates. Therefore, key factors in the management of antibiotic-resistant bacteria and preventing the spread 
of these resistance mechanisms are proper antibiotic usage and applicable infection control strategies. To the best of our knowledge, this is the first study in Turkey to detect isolates with co-existing $b / a_{\mathrm{VIM}}$ and $b / a_{\mathrm{IMP}}$ genes.

\section{Ethics}

Ethics Committee Approval: The study protocol was approved by Karadeniz Technical University Faculty of Medicine Ethic Council (decision date-number: 2011/7-2).

Informed Consent: Written informed consent of the patient was not obtained due to the retrospective nature of this study but hospital records were reviewed by the approval of the hospital management.

Peer-review: Externally peer-reviewed.

\section{Authorship Contributions}

Surgical and Medical Practices: Y.B., G.B., Concept: G.B., F.A., Design: Y.B., G.B., Data Collection or Processing: Y.B., N.K., Analysis or Interpretation: G.B., I.T., Literature Search: Y.B., G.B., Writing: Y.B.

Conflict of Interest: No conflict of interest was declared by the authors.

Financial Disclosure: The authors declared that this study received no financial support.

\section{References}

1. Hong DJ, Bae IK, Jang IH, Jeong SH, Kang HK, Lee K. Epidemiology and Characteristics of metallo- $\beta$-lactamase-producing Pseudomonas aeruginosa. Infect Chemother. 2015;47:81-97.

2. Cornaglia G, Giamarellou H, Rossolini GM. Metallo- $\beta$-lactamases: a last frontier for $\beta$-lactams? Lancet Infect Dis. 2011;11:381-93.

3. Malkoçoğlu G, Aktaş E, Bayraktar B, Otlu B, Bulut ME. VIM-1, VIM-2, and GES-5 Carbapenemases among Pseudomonas aeruginosa isolates at a tertiary hospital in Istanbul, Turkey. Microb Drug Resist. 2017;23:32834.

4. Bahar G, Mazzariol A, Koncan R, Mert A, Fontana R, Rossolini GM, Cornaglia G. Detection of VIM-5 metallo-beta-lactamase in a Pseudomonas aeruginosa clinical isolate from Turkey. J Antimicrob Chemother. 2004;54:282-3.

5. Ozgumus OB, Caylan R, Tosun I, Sandalli C, Aydin K, Koksal I. Molecular epidemiology of clinical Pseudomonas aeruginosa isolates carrying IMP1 metallo-beta-lactamase gene in a university hospital in Turkey. Microb Drug Resist. 2007;13:191-8.

6. Yakupogullari Y, Poirel L, Bernabeu S, Kizirgil A, Nordmann P. Multidrugresistant Pseudomonas aeruginosa isolate co-expressing extendedspectrum beta-lactamase PER-1 and metallo-beta-lactamase VIM-2 from Turkey. J Antimicrob Chemother. 2008;61:221-2.

7. Iraz M, Duzgun A0, Cicek AC, Bonnin RA, Ceylan A, Saral A, Nordmann P, Sandalli C. Characterization of novel VIM carbapenemase, VIM-38, and first detection of GES- 5 carbapenem-hydrolyzing $\beta$-lactamases in Pseudomonas aeruginosa in Turkey. Diagn Microbiol Infect Dis. 2014;78:292-4.

8. Er H, Altındiş M, Aşık G, Demir C. Molecular epidemiology of beta-lactamases in ceftazidime-resistant Pseudomonas aeruginosa isolates. Mikrobiyol Bul. 2015;49:156-65.
9. Zavascki AP, Barth AL, Gonçalves AL, Moro AL, Fernandes JF, Martins AF, Ramos $F$, Goldani LZ. The influence of metallo- $\beta$-lactamase production on mortality in nosocomial Pseudomonas aeruginosa infections. J Antimicrob Chemother. 2006;58:387-92.

10. Zaoutis TE, Goyal M, Chu JH, Coffin SE, Bell LM, Nachamkin I, McGowan $\mathrm{KL}$, Bilker WB, Lautenbach E. Risk factors for and outcomes of bloodstream infection caused by extended-spectrum $\beta$-lactamase-producing Escherichia coli and Klebsiella species in children. Pediatrics. 2005;115:942-9.

11. Clinical and Laboratory Standards Institute (CLSI). Performance standards for antimicrobial susceptibility testing; $20^{\text {th }}$ Informational Supplement (M100-S20);2010. Last Accessed date: 4 March 2019. Available from: https://www.researchgate.net/file.PostFileLoader.html?id=50f0395de 39d5e8368000022\&tassetKey=AS\%3A272 179910905 873\%401441 904155 623

12. Pitout JD, Gregson DB, Poirel L, McClure JA, Le P, Church DL. Detection of Pseudomonas aeruginosa producing metallo-beta-lactamases in a large centralized laboratory. J Clin Microbiol. 2005;43:3129-35.

13. Sepp R, Szabó I, Uda H, Sakamoto H. Rapid techniques for DNA extraction from routinely processed archival tissue for use in PCR. J Clin Pathol. 1994;47:318-23.

14. Mendes RE, Kiyota KA, Monteiro J, Castanheira M, Andrade SS, Gales AC, Pignatari AC, Tufik S. Rapid detection and identification of metallo-betalactamase encoding genes by multiplex real-time PCR assay and melt curve analysis. J Clin Microbiol. 2007;45:544-7.

15. Tsakris A, Pournaras S, Woodford N, Palepou MF, Babini GS, Douboyas J, Livermore DM. Outbreak of infections caused by Pseudomonas aeruginosa producing VIM-1 carbapenemase in Greece. J Clin Microbiol. 2000;38:12902.

16. Noyal MJ, Menezes GA, Harish BN, Sujatha S, Parjia SC. Simple screening tests for detection of carbapenemases in clinical isolates of nonfermentative Gram-negative bacteria. Indian J Med Res. 2009;129:707-12.

17. Pellegrino FL, Teixeira LM, Carvalho Md Mda G, Aranha Nouér S, Pinto De Oliveira M, Mello Sampaio JL, D'Avila Freitas A, Ferreira AL, Amorim Ed Ede L, Riley LW, Moreira BM. Occurrence of a multidrug-resistant Pseudomonas aeruginosa clone in different hospitals in Rio de Janeiro, Brazil. J Clin Microbiol. 2002;40:2420-4.

18. Ballarini A, Scalet G, Kos M, Cramer N, WiehImann L, Jousson O. Molecular typing and epidemiological investigation of clinical populations of Pseudomonas aeruginosa using an oligonucleotide-microarray. BMC Microbiol. 2012;12:152.

19. Rizek C, Fu L, Dos Santos LC, Leite G, Ramos J, Rossi F, Guimaraes T, Levin AS, Costa SF. Characterization of carbapenem-resistant Pseudomonas aeruginosa clinical isolates, carrying multiple genes coding for this antibiotic resistance. Ann Clin Microbiol Antimicrob. 2014;13:43.

20. Castanheira M, Deshpande LM, Costello A, Davies TA, Jones RN. Epidemiology and carbapenem resistance mechanisms of carbapenem-non-susceptible Pseudomonas aeruginosa collected during 2009-11 in 14 European and Mediterranean countries. J Antimicrob Chemother. 2014;69:1804-14.

21. Baran I, Aksu N. Phenotypic and genotypic characteristics of carbapenemresistant Enterobacteriaceae in a tertiary-level reference hospital in Turkey. Ann Clin Microbiol Antimicrob. 2016;15:20.

22. Kilic A, Aktas Z, Bedir O, Gumral R, Bulut Y, Stratton C, Tang YW, Basustaoglu AC. Identification and characterization of OXA-48 producing, carbapenem-resistant Enterobacteriaceae isolates in Turkey. Ann Clin Lab Sci. 2011;41:161-6.

23. Sahin K, Tekin A, Ozdas S, Akin D, Yapislar H, Dilek AR, Sonmez E. Evaluation of carbapenem resistance using phenotypic and genotypic techniques in Enterobacteriaceae isolates. Ann Clin Microbiol Antimicrob. 2015;14:44.

24. Aksoy MD, Çavuşlu Ş, Tuğrul HM. Investigation of metallo beta lactamases and oxacilinases in carbapenem resistant Acinetobacter baumannii strains isolated from inpatients. Balkan Med J. 2015;32:79-83. 
25. Kulah C, Mooij MJ, Comert F, Aktas E, Celebi G, Ozlu N, Rijnsburger MC, Savelkoul PH. Characterisation of carbapenem-resistant Acinetobacter baumannii outbreak strains producing OXA-58 in Turkey. Int J Antimicrob Agents. 2010;36:114-8.

26. Gupta V. Metallo beta lactamases in Pseudomonas aeruginosa and Acinetobacter species. Expert Opin Investig Drugs. 2008;17:131-43.

27. Walsh TR, Toleman MA, Poirel L, Nordmann P. Metallo-beta-lactamases: the quiet before the storm? Clin Microbiol Rev. 2005;18:306-25.

28. Lucena A, Dalla Costa LM, Nogueira KS, Matos AP, Gales AC, Paganini MC, Castro ME, Raboni SM. Nosocomial infections with metallo-betalactamase-producing Pseudomonas aeruginosa: molecular epidemiology, risk factors, clinical features and outcomes. J Hosp Infect. 2014;87:23440.
29. Nouér SA, Nucci $M$, de-Oliveira MP, Pellegrino $F L$, Moreira BM. Risk factors for acquisition of multidrug-resistant Pseudomonas aeruginosa producing SPM metallo-beta-lactamase. Antimicrob Agents Chemother. 2005;49:3663-7.

30. Hirakata Y, Yamaguchi T, Nakano M, Izumikawa K, Mine M, Aoki S, Kondoh A, Matsuda J, Hirayama M, Yanagihara K, Miyazaki Y, Tomono K, Yamada Y, Kamihira S, Kohno S. Clinical and bacteriological characteristics of IMPtype metallo-beta-lactamase-producing Pseudomonas aeruginosa. Clin Infect Dis. 2003;37:26-32.

31. Laupland $K B$, Parkins MD, Church DL, Gregson DB, Louie TJ, Conly JM, Elsayed S, Pitout JD. Population-based epidemiological study of infections caused by carbapenem-resistant Pseudomonas aeruginosa in the Calgary Health Region: importance of metallo-beta-lactamase (MBL)-producing strains. J Infect Dis. 2005;192:1606-12. 